\title{
The Lure of Independence
}

\author{
Book Review
}

STEPHEN STOCKWELL

GRIFFITH UNIVERSITY

Brian Costar and Jennifer Curtin

Rebels with a Cause: Independents in Australian Politics

University of New South Wales Press, Sydney, 2004

ISBN: 0-86840-695-3

RRP \$16.95 (pb)

Political independents have played a surprisingly large role in Australian politics over the last fifteen years, holding the balance of power in five of Australia's six states. The Australian Capital Territory and the federal Senate and have played a major role in keeping governments honest, making ministers more accountable and reforming parliament. Brian Costar and Jennifer Curtin's ninety-five page monograph is the least the phenomenon deserves. At one level their book, Rebels with a Cause, provides systematic documentation of 'the independents' movement', a movement that refuses to be a movement representing, as it does, the wide diversity of opinion available outside the centrist interests of the major political parties.

Costar and Curtin provide chapters on the independents in the states and their achievements in gaining charters of good government and the like in return for propping up one side or the other in government. Further chapters look at independents in the Senate and 
independent icons from the past including North Queenslanders Frank 'Bombshell' Barnes and Tom Aitken, 'firebrand orator, wit and notoriously spectacular public drunkard' who, forswearing alcohol, was elected to state parliament by the people of Townsville South twelve times between 1944 and 1960. There is also a chapter by Peter Browne on Peter Andren's success in rural Calare in 2001 despite the unpopularity of his support for refugees among the electorate. The book is rounded out with an appendix of all independent federal lower house MPs since federation and all the state and territory independents since the 1960s, though no systematic list of independents in the Australian senate.

But Costar and Curtin go further, raising pertinent questions about the failures, excesses and limitations of the two-party duopoly of political power that prevails in parliamentary democracies around the world. In short, if the legitimacy of democracy rests on the informed acquiescence of the citizens, as democratic theory argues. then where do we draw the line between the 'permanent campaign' of either government's self-promotion and their manipulation of institutions, public servants and the facts in ways that undermine the free flow of information on which the citizen's sovereignty rests?

The Australian 2001 Tampa/children overboard election still rankles the democratic theorist because the government used the threat of terrorism and its control of the information flow so effectively to construct a campaign that could not fail. The ostensibly political question of information flow should rightly be of immense interest to cultural studies because it is predominantly a cultural question and it goes to the heart of the narrative that democracy spins around itself.

Costar and Curtin are first and foremost political scientists, so it is interesting to note that though their work genuflects to the empirical with small quantitative and qualitative surveys, a couple of tables and some statistical analysis, the authors are quick to take the cultural turn when seeking to come to grips with the issues. The study of political culture has long had a niche in the outer suburbs of political science. I remember the moment of liberation when I was an undergraduate circa 1973, wading through the 805 pages of Henry Mayer and Helen Nelson's Australian Politics: A Third Reader and coming across a chapter on the political culture of Australia.

The 2004 Australian Political Studies Association (APSA) Conference introduced a stream on media and popular culture and this conference has long had a gender and sexuality stream. Most of the papers in these streams would not be out of place at the Cultural Studies Association of Australasia conference and though there were plenty of statistics in other streams at APSA for those keen on a mathematical challenge, those streams also embraced methodologies from the psychological to the Foucauldian. Even the most inveterate number-crunchers were pressed to reflect on what the numbers mean, on what their cultural significance is. 
Before turning to look at the questions for cultural studies raised by Costar and Curtin, let me raise an issue of political science. If they are going to pay homage to the numerical, and I am the first to admit that the quantitative propensity supplies much of political science's mystique and charm, then let's get the numbers right. On page 34 it is claimed that Queensland's coalition had forty-two MPs after the 1998 state election when in fact they had thirty-two.

These mathematical infelicities are relatively unimportant when considered alongside the cultural work of the independents' movement. Independent politicians have taken a major role in revealing the play of power behind government media management. As independents, generally, are far from government power and do not even desire it in most cases, they are well positioned to show how the system works, to limit its excesses and to bargain for improvements. Queensland independent Peter Wellington, for example, is given credit for insisting on regular cabinet meetings in the community as part of the pact he made in 1998 to support the first Beattie government. Even Premier Beattie sings the praises of community cabinets as a means of keeping in touch with the electorate and they continue monthly even though he has won two landslide elections since their inception.

One interesting point raised by Costar and Curtin is the 'disproportionate number' of independents from rural and regional constituencies-twenty-eight of the forty-eight independents elected to Australia's lower houses since 1990 have been from regional and rural areas. The reason that so many independents come from beyond the metropolis is not that the bush harbours a plethora of fair-minded voters dispassionately balancing the power of parties in the interest of good democracy. Rather, those outside the metropolis feel angry, alienated and alone. They feel the wealth and opportunities of the city have by-passed them. This is the same hurt that turned the independent Pauline Hanson (even though she had Liberal beside her name on the ballot paper in the only election she ever won) into her own political brand. While cultural studies has been bewitched by the racism in Pauline's presentation, it has failed to come to terms with the cultural issues in regional and rural Australia that have powered her rise to prominence. Pauline has passed as a political force, but Hansonism is still potent in Australian politics and has assisted John Howard to victory at the last two federal elections.

Rebels with a Cause is well worth close scrutiny by any scholar interested in the perils and possibilities facing Australian politics, and culture.

Stephen Stockwell is Associate Professor in Journalism and Public Relations at the School of Arts, Griffith University. His research interests are around the politics-media interface and he has previously worked as a press secretary for federal and state politicians and as a political journalist for 4ZZZ, Triple J and Four Corners. 